Ирена М. Кужник"

Борко Н. Ковачевић

Универзитет у Београду

Филолошки факултет
$81>272$

https://doi.org/10.18485/analiff.2019.31.1.8

Originalni naučni rad

Primljen: 22.05.2019

Prihvaćen: 25.08.2019

\title{
РЕЛЕВАНТНОСТ КОНЦЕПТА РЕВИТАЛИЗАЦИЈЕ ЈЕЗИКА ИЗ ПЕРСПЕКТИВЕ САВРЕМЕНИХ ОБРАЗОВНИХ ПОЛИТИКА
}

У раду се анализира појам ревитализације језика и разматра концепт њене примене као начина очувања језика у савременом добу. Једним од предуслова успешне језичке обнове у неком друштвеном окружењу сматра се језичка стандардизација, којом се поставља основ за стварање афирмативних ставова према етничком језику унутар обеју заједница - мањинске и већинске. Међу приступима језичкој ревитализацији наводе се промена смеpa језичке замене, затим grass roots иницијативе, теорија друштвених мрежа, као и значај bottom-up и top-down смерова језичке политике - како на националном, тако и на интернационалном плану. Уз осврт на одређене социолингвистичке елементе и околности, у раду се као посебан пример обрађује случај словеначког језика и његовог актуелног статуса у образовном систему Републике Србије.

Кључне речи: ревитализација језика, језичка политика, говорна заједница, мањински језик, словеначки језик

\section{1 Увод}

Настајање и нестајање језика сматра се саставним делом историје језика, па самим тим и људске историје. Различити су разлози за нестанак неког језика, односно за постанак неког новог. Факторе који утичу на опстанак језика у некој заједници UNESCO дели на екстерне - војне, економске, верске, културне или образовне, и интерне - када

* irenakuznik@gmail.com 
Ирена М. Кужник / Борко Н. Ковачевић

сама заједница има негативан став према сопственом језику, односно када говорници неког језика нестану или почну да се служе другим језиком. Управо ово последње је у савременом добу повећаних миграција и све присутније урбанизације постало основни начин слабљења виталности неког језика и подлегања притиску употребе неког доминантног језика, језика шире говорне заједнице, који се перципира као неопходан за економски и општедруштвени развој.

Према проценама UNESCO, уколико се савремени тренд нестајања језика настави, до краја овог века половина језика који се тренутно говоре ће нестати или ће бити озбиљно угрожена. Нажалост, ово су оптимистичке прогнозе, док су песимистичке, али и реалније и извесније процене, много озбиљније: чак 90-95 \% светских језика, првенствено аутохтоних, очекује један од поменута два исхода, док се кроз исту призму може посматрати и опстанак мањинских језика (McCarty, Skutnabb-Kagnas, Magga 2008: 297).

Имајући у виду чињеницу да је језик не само основно средство комуникације и споразумевања међу људима, већ да представља и огледало идентитета и културе неког народа, може се, у контексту промоције вишејезичности, тврдити да учење, познавање и коришћење више од једног језика није само преимућство појединца, већ и целог друштва, те тиме губитак било ког језика на свету представља огромно осиромашење за човечанство (McCarty, Skutnabb-Kagnas, Magga, 2008: 298). Право на употребу језика једно је од основних људских права, и неговање матерњег језика би требало да иде у корак са неговањем и већинских и мањинских језика.

Тежња ка проактивнијем приступу решавању свеприсутног проблема угрожености језика допринела је развоју и значају концепата одржавања и ревитализације језика. С обзиром на то да су оба покрета релативно новијег датума, као и да ревитализација представља, на одређени начин, надградњу процеса језичког одржавања, у наставку текста биће објашњен термин ревитализације језика, као и одређени видови њене примене као начина очувања језика у савременом добу. Поред тога, кроз илустроване примере биће разматрана и успешност досадашњих иницијатива и приступа, са посебним фокусом на случај словеначког језика и његов статус мањинског језика у Републици Србији. 
РЕЛЕВАНТНОСТ КОНЦЕПТА РЕВИТАЛИЗАЦИЈЕ ЈЕЗИКА ...

\section{2 Концепт језичке ревитализације}

У општем смислу, појам ревитализације језика подразумева покушај да се спречи, заустави или промени смер опадања употребе неког језика, или да се оживи језик који се сматра изумрлим. Поменуто се остварује повећавањем броја говорника предметног језика, односно проширењем његове употребе, као и одржавањем постојећег нивоа употребе у циљу спречавања изумирања или смрти тог језика. Поред тога, ревитализација представља и један од циљева језичког документовања, као дисциплине у којој лингвисти стварају и чувају записе о граматици, вокабулару и лингвистичким карактеристикама одређеног језика. Иако поједини аутори праве дистинкцију између термина ревитализације (енг. language revitalization) и оживљавања језика (енг. language revival), преовлађују ставови о њиховој међусобној испреплетаности, односно ревитализацији као категоријално обухватнијем појму, те ће се у том смислу и третирати у наставку текста.

Према Хинтон (2003: 45-47), језичка ревитализација као покрет доживљава свој пуни развој тек током 1990-их година, када и долази до значајнијег пораста стручне литературе на ову тему. У периоду пре тога, седамдесетих и осамдесетих година прошлог века, покушаји очувања језика (енг. language maintenance) имали су облик тежње да се одржи status quo мањинских језика кроз документовање, бележење, увођење билингвалног образовног програма код дотадашњих монолингвалних говорника друштвено доминантних језика, итд. Прелаз са очувања језика на ревитализацију као фокус рада језичких заједница и стручњака у последњој деценији 20. века десио се управо услед спознаје алармантног стања изумирања језика и тежње да се језици „спасу“. Конкретније, поменуто спашавање огледа се у стремљењу ка томе да се припадницима мањинских заједница, којима је из неког разлога онемогућен нормални трансгенерацијски пренос језика, пружи прилика да науче сопствени језик (Филиповић, 2009: 103). То подразумева стварање повољних услова говорницима да говоре свој језик и да своју децу уче том језику, што између осталог захтева и постојање језичких политика које би уважиле и заштитиле мањинске језике у свим друштвеним доменима унутар вишејезичне заједнице, а затим и на националном и интернационалном плану. 
Ирена М. Кужник / Борко Н. Ковачевић

Филиповић (2009: 98) дефинише ревитализацију као покушај да се варијетету, односно мањинском језику који се под утицајем социјалних и/или политичких фактора већ налази у процесу замене (енг. language shift) од стране доминантног, већинског језика, поново доделе комуникативна својства у различитим доменима друштвене употребе, чиме се омогућава његов даљи опстанак у предметној заједници. Тиме се, заправо, друштвено окружење - оно које је првобитно, различитим узроцима, довело до опадања употребе језика - користи као средство "оживљавања" истог тог језика у датој говорној средини.

Тај двојаки и двосмерни однос језика и друштва, преплитање њихове истовремене симбиозе и антагонизма, говори у прилог тврдњи да су ревитализација, одржавање, замена, па чак и смрт језика производи интеракције већинских и мањинских језика у социјалном, политичком и економском окружењу. Отуда је логично да се положај језика у неком друштвеном ентитету мора првенствено посматрати кроз призму саме људске заједнице - како мањинске, тако и већинске - као и сваког њеног појединачног члана. При томе је неопходно у обзир узети и језичке политике - и званичне и незваничне - које појединцима, условно речено, диктирају схватања о сопственом језику, идентитету и култури, као и ставове према већинским/другим културама, етницитетима и језицима (Филиповић, 2009: 103). С друге стране, на формирање и опсеге језичких политика утичу културни модели и идеологије установљени унутар саме заједнице као тзв. интерни фактори, али и друштвене норме и вредности већинске заједнице, односно екстерни фактори (Филиповић, 2009: 99). Из наведених сегмената међусобне повезаности употребе језика, друштвеног окружења и језичких политика, може се закључити да језичка стандардизација представља предуслов за успешну ревитализацију, као и за развој позитивних ставова према етничком језику унутар обеју заједница, мањинске и већинске.

\section{3 Неки приступи и примери ревитализације језика}

У контексту језичке политике и планирања, као и уопште посматрања језика кроз социолошку призму са циљем разумевања свих околности које су довеле до потребе за ревитализацијом, неопходно је поменути термин иромена смера језичке замене (енг. reversing 
РЕЛЕВАНТНОСТ КОНЦЕПТА РЕВИТАЛИЗАЦИЈЕ ЈЕЗИКА ...

language shift-RLS). У литератури се овај термин често поистовећује са ревитализацијом и, заједно са терминима попут оживљавања језика, ресторације и рестабилизације, наводи као један од њених синонима.

Сам термин и концепт промене смера језичке замене први је установио и осмислио Џошуа Фишман, полазећи од односа језика и културе, њиховог међусобног утицаја, као и уверења и ставова о њиховом односу, а које чланови заједнице преносе са генерације на генерацију. Језгро тог односа налази се управо у породици и преносу матерњег језика кроз сопствене ресурсе (са мајке на дете) и природне колективне процесе (у ужој породици и ужој заједници), а без већег утицаја ширег социолошког планирања ( Фипман 1991: 67). Отуда се успешност RLS по Фишману заснива на спознаји неке врсте социокултурне самодовољности у контексту напора ка очувању етничког језика на нивоу породице и локалне заједнице (Фишман 1991:4). Томе у прилог говори и феномен који је Фишман назвао "језичком лојалношћу" односно тенденцијом очувања језика у некој мањој или већој заједници - не због његове практичне сврхе и комуникативне намене, већ као носиоца идентитета неког народа и одраза његове културе.

Јединствени пример успешног RLS представља хебрејски језик који се од статуса светог језика јудаизма очуваног у ретким верским списима трансформисао у писани и говорни језик у свакодневној употреби у Израелу. Кључни фактори који су допринели томе да овај језик дође до статуса језика са неколико милиона матерњих говорника јесу управо подстицање употребе језика у породичном и блиском окружењу у комбинацији са билингвалним образовањем, односно позитивним ставом говорне заједнице, као и институционалном подршком кроз афирмативну језичку политику и планирање.

Додатни допринос развоју социолингвистичке теорије Фишман је дао осмишљавањем концепта іраяиране иниееріенерацијске скале иррекияа ${ }^{1}$ (енг. Graded Intergenerational Disruption Scale - GIDS), односно скале процене угрожености неког језика. Створена по узору на Рихтерову скалу магнитуде земљотреса (Hinton 2003: 49), GIDS скала обухвата 8 стадијума губитка језика, у распону од првог степена - на којем се језик користи у већини домена употребе, односно сфера свакодневног живота - до осмог степена, као највишег стадијума угро-

1 Превод назива скале на српски језик преузет из: Вучина Симовић, Филиповић 2009: 23 
Ирена М. Кужник / Борко Н. Ковачевић

жености, где језик употребљавају само старији говорници који су, при томе, и друштвено изоловани.

Терминологијом коју је увео у концепт језичке ревитализације, Фишман је настојао да подстакне проактивно истраживање опстанка језика, да би показао да процес језик-у-друштву може бити и двосмеран, и да није потребно инсистирати на очувању језика само на институционалном плану, већ се првенствено окренути нивоу породице и шире заједнице, са нагласком на међугенерацијски пренос матерњег језика.

На Фишманов концепт значаја употребе етничког језика у круговима породице и уже заједнице као централним тачкама преноса надовезују се и Гарсија (Garcia, 2003: 22) и Литлбер, који наглашава да породице морају повратити своју заслужену улогу првог учитеља језика (Литлбер 1996: 13, цит. у Hinton, 2003: 48).

У мало ширем контексту, на нивоу заједнице, одличне примеpe ревитализације језика представљају две грађанске (енг. grass roots) иницијативе - маорска и хавајска, покренуте мотивацијом чланова своје заједнице, односно родитеља који су се изборили за имерзионе образовне програме. У суштини, ти програми подразумевају реконструкцију природног окружења за учење аутохтоног језика - и то не само за децу, већ и за наставнике и саме родитеље - путем стварања тзв. "језичких гнезда", где су старији говорници језика директно укључени у образовање млађих управо кроз међугенерацијски пренос. Термин потиче са Новог Зеланда и први пут је употребљен током 80-их година прошлог века за означавање посебног приступа ревитализацији маорског језика имерзионим образовањем у раном дечјем узрасту.

У периоду после Другог светског рата, па све до 1980-их, дошло је до знатног опадања у броју говорника до тада доминантног маорског језика на Новом Зеланду, услед чега се појавила забринутост од његовог могућег изумирања. Прекретница се догодила 1982. године, када је, уз подршку власти, основано прво "језичко гнездо" у вртићима и предшколским установама. Уследило је доношење Закона о маорском језику 1987. године, као и увођење и шира примена овог приступа у основним и средњим школама од 1989. године.

Слично маорском, и хавајски језик је, након доминантне улоге током 19. века, крајем прошлог века доживео судбину драстичног смањења употребе у практично свим друштвеним доменима. Штави- 
РЕЛЕВАНТНОСТ КОНЦЕПТА РЕВИТАЛИЗАЦИЈЕ ЈЕЗИКА ...

ше, до 1990. године, како наводи Хинтон (2003: 51), матерњи говорници млађи од 50 година нису више уопште ни постојали, осим на малом острву Нихау. По узору на маорски програм, оснивање "језичких гнезда" у вртићима и предшколским установама, а касније и на вишим нивоима образовања, довело је до стварања генерација билингвалне деце која подједнако добро владају и енглеским и хавајским језиком.

Чињеница да су, услед различитих друштвених, историјских и политичких чинилаца, оба аутохтона језика седамдесетих година прошлог века била на 7. односно 8. степену према Фишмановој GIDS скали, а да су, после само пар деценија, оба језика достигла статус званичног уз енглески језик (McCarty, Skutnabb-Kagnas, Magga, 2008: 304) потврђује, не само успешност поменутог принципа, већ и неопходност свеобухватног системског приступа језичком управљању на нивоу друштвене заједнице.

Међу врстама социолингвистичких истраживања релативно новијег датума налази се теорија друштвених мрежа (енг. social network theory), на чији значај међу првима указује ауторка Ен Лесли Милрој. Уопштено гледано, ова теорија подразумева да сваки појединац својим деловањем припада одређеној друштвеној мрежи, а да везе, односи и интеракције између појединаца у оквиру друштвених мрежа директно утичу на одржавање и очување језика унутар те мреже, односно друштва.

Полазни основ истраживања Милројеве, по схватању Местрија (Mesthrie 2008: 72), није било проучавање појединачних говорника као припадника неке апстрактне друштвене групе која припада одређеној друштвеној класи, већ начина на који њихово говорно понашање кореспондира са природом њихових свакодневних друштвених контаката. Из наведеног се једноставније може закључити да се овим методом не анализира само мањински језик који појединци користе у комуникацији са другим члановима унутар своје етничке групе, већ и њихово међусобно дејство и комплексност односа унутар групе, а на најширем плану и интеракције које остварују изван те групе са другим групама унутар етнојезичке заједнице.

У свом тумачењу, аутори Де Бот и Стесел сматрају да теорија друштвених мрежа сугерише ужи приступ очувању језичког идентитета, заснован на размени порука међу појединцима унутар њихових сопствених мрежа, чиме се јача комуникација на мањинском језику 
Ирена М. Кужник / Борко Н. Ковачевић

и смањује могућност замене језика на нивоу заједнице (Garcia, 2003: 25). Међутим, имајући у виду да је језик отворен систем, подложан утицајима и променама, овде би се евентуално могло поставити питање да ли је овај приступ, иако „безбедан“ и сигуран за опстанак и неговање језика, ипак превише херметичан, и да ли, осим очигледне добробити за језичку заједницу, ипак са собом носи и неку врсту ограничења или негативних ефеката за њене чланове.

Како истиче Филиповић (2009: 28), теорија друштвених мрежа је као приступ погодна у истраживању разлога очувања одређених језичких варијетета у некој вишејезичној заједници, односно опстанка мањинског језика у односу на доминантни, већински језик у широј употреби, који су примарно засновани на социокултурном значају и вредности које том језику придају сами говорници. Управо захваљујући говорницима који употребу језика сматрају симболом идентитета и одразом припадности етничкој заједници и тиме подржавају његово очување, могло би се закључити да језик представља ресурс применљив у различитим социокултурним употребним доменима (Филиповић 2009: 104).

Гледано из перспективе језичке политике и планирања, већина приступа језичкој ревитализацији везује се за институционални контекст, односно подршку државних и владиних институција кроз доношење и спровођење релевантних закона и прописа - у смеру језичке политике "одозго надоле" (енг. top-down). Примена супротног смера језичког планирања "одоздо нагоре" (енг. bottom-up) подразумева ангажовање првенствено етничких говорника у заједници, али и различитих сегмената цивилног друштва, на очувању језика, и њихово деловање према институционалним доносиоцима одлука.

У овом контексту, ревитализацију мањинског језика можемо разумети као активност, иницијативу саме заједнице да кроз bottomup језичку политику утиче на формирање језичке политике ревитализације на својој територији. Свакако, тај процес није једносмеран, постоји повратна спрега; активност мора постојати и у супротном, top-down смеру језичке политике институција државе, које би требало да пруже подршку на плану поштовања националног и интернационалног законодавства (Филиповић, 2009: 105). Ова два смера, иако супротна, не би требало схватити као контрадикторне, већ као комплементарне приступе чији су синергија и уравнотеженост утицаја 
РЕЛЕВАНТНОСТ КОНЦЕПТА РЕВИТАЛИЗАЦИЈЕ ЈЕЗИКА ...

неопходни предуслови успешне ревитализације мањинских језика.

Као пример једне такве избалансиране спреге утицаја и напора може се узети пример словеначког језика у Србији. У основи ревитализације овог језика у Србији мисли се на његову ревитализацију у образовном систему.

\section{4 Случај словеначког језика у Републици Србији}

Судећи по броју званично признатих националних мањина и опсегу националног законодавног оквира којим се уређују њихова права и слободе, Република Србија сврстава се међу водеће европске земље. Поред Уставом загарантованих права свим грађанима, националне мањине остварују и додатна права у складу са домаћом регулативом и међународним документима, а кроз које им је омогућено учешће и одлучивање о релевантним питањима у вези са њиховом културом, образовањем, информисањем и службеном употребом језика и писма.

Према подацима Канцеларије за људска и мањинска права Владе Републике Србије, у нашој земљи тренутно постоје 23 национална савета националних мањина. У извештају из 2017. године, Министарство просвете, науке и технолошког развоја наводи да се настава у 1.240 основних школа изводи на српском наставном језику, на језику 8 националних мањина (албанском, бугарском, босанском, мађарском, румунском, русинском, словачком и хрватском), као и комбиновано на српском језику и језику националне мањине. Овоме би требало додати новији податак да је, у школској 2018/2019. години, у једној основној школи у Новом Саду као изборни предмет у првом разреду уведен и Словеначки језик са елементима националне културе, а у складу са релевантним Правилником Министарства просвете, науке и технолошког развоја из 2017. године.

Од наведених језика, може се рећи да су управо они који, заједно са српским, припадају групи јужнословенских језика одувек имали специфичан статус на територији наше земље. Њихова посебност - конкретно се мисли на данашњи хрватски (део некадашњег српскохрватског), македонски и словеначки језик - датира из периода између два светска рата, времена Краљевине Срба, Хрвата и Словенаца, као и њиховог статуса језика у службеној употреби у бившој Соција- 
Ирена М. Кужник / Борко Н. Ковачевић

листичкој Федеративној Републици Југославији. Поред историјске и просторне блискости, поменути језици су и у лингвистичком смислу најсроднији српском језику, те се њихов специјални статус у периоду након нестанка СФРЈ, у Савезној Републици Југославији, а коначно и у Републици Србији, у једној мери заснива и на постојању великог броја говорника, односно припадника наведених националних мањина, као и на одређеном сентименту између самих народа, везаном за некадашње јединство.

Сукоби који су избили током 1990-их, затим распад заједничке државе, као и бурне политичке и друштвене промене које су уследиле на овим просторима, неминовно су утицале и на промену статуса и перцепције појединачних националних језика. С обзиром на то да се језик одувек повезивао са јачањем свести о припадности и националном идентитету, не може се тврдити да су, за то време својствена, истицања тројства ,једна држава - једна нација - један језик“ и наглашавање потребе да свака држава формирана распадом бивше СФРЈ има сопствени језик, била изненађење (Кужник, 2016: 160).

Данас смо сведоци чињенице да језици, којима је својевремено Уставом СФРЈ била загарантована равноправност у употреби на територији заједничке државе, имају статусе мањинских, односно страних језика у појединачним државама. Питања статуса тих језика, односно разлози због којих поједини језици у одређеним државама немају очекивани статус мањинског језика, заслужују да буду предмет одвојеног рада, те се овом приликом у њих неће залазити.

У наставку ће, из перспективе утицаја националних језичких политика на учење страних језика, бити илустрован случај словеначког језика, његов статус као језика националне мањине у Републици Србији, као и околности које су допринеле његовој својеврсној ревитализацији на универзитетском нивоу.

Уколико изузмемо пример недавно уведеног словеначког језика као изборног предмета у основној школи, једине две институције у нашој земљи у којима је могуће учити овај језик организовано и под покровитељством Министарства просвете, науке и технолошког развоја Републике Србије јесу Филолошки факултет у Београду и Филозофски факултет у Новом Саду. Имајући у виду да је словеначки језик на Филозофском факултету у Новом Саду тренутно у статусу двосеместралног изборног курса при Одсеку за српски језик и линг- 
РЕЛЕВАНТНОСТ КОНЦЕПТА РЕВИТАЛИЗАЦИЈЕ ЈЕЗИКА ...

вистику, биће изложен краћи преглед историјата наставе словеначког језика на Филолошком факултету у Београду.

На београдском Универзитету се учење словеначког језика везује за сам почетак прошлог века, односно када је проф. Павле Поповић одржао први курс словеначке књижевности на тадашњој Великој школи 1905. године, затим две године касније увео и курс словеначког језика намењен будућим преводиоцима, док је сама настава словеначког језика први пут званично прописана Статутом из 1947. године на тадашњем Филозофском факултету (Ђукановић 20116 : 110). Више од пет деценија XX века је словеначки језик на Филолошком факултету у Београду имао статус обавезног једногодишњег предмета за две студијске групе: на Катедри за српски језик и јужнословенске језике и на Катедри за српску књижевност и југословенске књижевности (Ђукановић М. \& Ковачевић Б, 2011а: 344-346).

Промену статуса овај језик доживљава током 1990-их година, када престаје да буде обавезан предмет на Филолошком факултету, смањује се фонд часова и он добија статус изборног предмета за студенте српског језика, чему су, између осталих, допринели и бројни друштвени, политички и идеолошки чиниоци (Ђукановић, 2007: 386). Статус словеначког језика, односно његово својеврсно „утихњавање“ на Универзитету у Београду у том периоду, представљало је, на одређени начин, неку врсту рефлексије односа двеју држава, али и потврду тврдње да је избор језика наставе у директном односу са идеологијом креатора језичких политика, као и односима на међународном тржишту (Кужник, 2014: 73). Већ почетком овог века, постепеним отварањем путева економске, културне и академске сарадње између Републике Србије и Републике Словеније, долази до пораста интересовања за учење овог мањинског језика и међу члановима немањинских заједница.

Кључни тренутак у универзитетској ревитализацији словеначког језика на Филолошком факултету у Београду представља имплементација Болоњске реформе 2006. године. У тој школској 2006/2007. години по први пут су уведене четворогодишње студије словеначког језика при Катедри за општу лингвистику, уз могућност њиховог комбиновања са студијама опште лингвистике или са студијама било ког страног језика који се изучава на Филолошком факултету (Ђукановић М. \& Ковачевић Б, 2011а). Поред основних студија, словенистички 
Ирена М. Кужник / Борко Н. Ковачевић

предмети заступљени су и на мастер и на докторским академским студијама овог Факултета.

Узимајући у обзир да данас на Филолошком факултету у Београду постоји посебан Лекторат за словеначки језик при Катедри за општу лингвистику, као и да се број студената који се интересују за проучавање словеначког језика и културе из године у годину знатно повећава, може се сматрати да је овај јужнословенски језик доживео својеврсну ревитализацију на универзитетском нивоу.

\section{5 Закључак}

Из свих приказаних приступа и примера језичких ревитализација у свету - од промене смера језичке замене, преко друштвених мрежа, до грађанских иницијатива - као заједнички именитељ може се издвојити афирмативан став говорника и говорне заједнице - била то породица или нека шира друштвена група - према сопственом језику као носиоцу идентитета те заједнице и одраза њене културе. Намеће се закључак да је у ревитализацији језика кључни фактор успешности заправо начин на који нека етнолингвистичка група доживљава сопствени језик, његов значај и опстанак у некој социјалној средини. Томе би се могла додати и одлучност и спремност на неопходан пратећи bottom-up ангажман те заједнице на стварању ширег друштвеног и политичког окружења које у другом смеру, кроз top-down приступ, подржава плурилингвизам релевантним законодавним оквиром и поштује мањинске језике, и то на такав начин да се употреба неког од мањинских језика на крају сматра додатним преимућством, како појединаца, тако и целе заједнице.

Еволуција наставе словеначког језика на београдском Филолошком факултету у последњих тридесетак година- од статуса изборног предмета за студенте двеју студијских група, до посебног Лектората за словеначки језик - представља модеран пример успешне језичке ревитализације на највишем могућем ступњу образовног система неке државе. Заслуга на првом месту припада Лекторату за словеначки језик и Катедри за општу лингвистику Филолошког факултета у Београду, али и студентима и припадницима мањинских и немањинских заједница, који су допринели актуелном статусу словеначког језика управо сопственим деловањем, академском заинтересо- 
РЕЛЕВАНТНОСТ КОНЦЕПТА РЕВИТАЛИЗАЦИЈЕ ЈЕЗИКА ...

ваношћу и указивањем на значај његовог изучавања у једној мултикултуралној и мултиетничкој средини каква је Република Србија.

Имајући у виду успешност примера словеначког језика у нашој земљи, остаје нада и очекивање да ће позитиван пример Републике Србије пратити и Република Словенија обезбеђивањем адекватног статуса српског језика, као и друге државе у региону.

\section{ЛИТЕРАТУРА:}

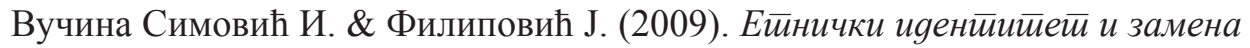
језика у сефаряској зајеgници у Беоіраяу. Београд: Завод за уџбенике и наставна средства.

Ђукановић М. (2014). Slovenščina v Srbiji: preteklost, sedanjost in prihodnost. Из: Тивадар Х. (ур.) 50. seminar slovenskega jezika, literature in kulture: Prihodnost slovenščine in slovenistik po svetu - Zbornik (пп. 177-184). Љубљана: Znanstvena založba Filozofske fakultete.

Ђукановић М. \& Ковачевић Б. (2011а). Достигнућа у настави словеначког језика као страног, из: М. Дешић, В. Крајишник \& Н. Маринковић (ур.), Срйски као стирани језик у тееорији и ирракси II, 343-359. Београд: Чигоја штампа.

Ђукановић, М. (2011б). Domestic or foreign? (the Slovenian language in light of the Bologna Reform Process at the University of Belgrade). Из: А. Bedkowska-Kopczyk, Lj. Šarić, L. Pavera (yp.), Challenges for Foreign Philologies. Part 1: The Bologna Process and New Curricula, (пп. 109113). Bielsko-Biała: Akademia Techniczno Humanistyczna w BielskuBiałej.

Ђукановић М. \& Сабо А. (2011в). Pomen poznavanja slovenskega jezika in kulture pri zaposlitvi mladih slovenskega rodu v Srbiji. 6. mednarodna konferenca: Družbena odgovornost in izzivi časa 2011 - „Mladi v presečišč svetovnih sprememb“ (књига апстраката). Марибор: Inštitut za razvoj družbene odgovornosti.

Ђукановић М. (2007). Ко, где, када, како и зашто треба да учи словеначки. Из: Вучо, J. (ур.) Савремене тиеняенције у настиави језика и књижевносиии. Зборник радова (пп. 385-390). Београд: Министарство за науку и заштиту животне средине.

Филиповић J. (2009). Моћ речи: ойлеgи из критиччке сочиолинївистиике. Београд: Задужбина Андрејевић. 
Ирена М. Кужник / Борко Н. Ковачевић

Fishman, J. A. (1991). Reversing language shift. Theoretical and empirical foundations of assistance to threatened languages. Clevedon: Multilingual Matters.

Garcia, M.E. (2003). Recent Research on Language Maintenance. Annual Review of Applied Linguistics 23, пп. 22-43.

Hinton, L. 2003. Language revitalization. Annual Review of Applied Linguistics 23, (пп. 44-57).

Кужник И. (2016). Језици у контакту: статус српског језика у Словенији и словеначког језика у Србији - коменйарисана библиоірафија. Из: Slovenika II (пп. 157-170). Београд: Национални савет словеначке националне мањине

Кужник И. (2014). Motivacija za učenje slovenščine kot maternega in manjšinskega jezika pri pripadnikih manjšinske in nemanjšinske skupnosti v Srbiji. Из: Дитмајер Н. (ур.) Zbornik študentske sekcije Slavističnega društva Slovenije 2 - Zbirka PhiloSlovenica (пп. 71-76). Марибор: Zveza društev Slavistično društvo Slovenije и Slavistično društvo Maribor.

Mesthrie, R. (2008) Sociolinguistics and Sociology of Language. Из: В. Spolsky and F. M. Hult (ур.) The Handbook of Educational Linguistics (пп. 66 82). Оксфорд, УК: Blackwell Publishing Ltd.

McCarty, T. L., Skutnabb-Kangas, T. and Magga, O. H. (2008) Education for Speakers of Endangered Languages. Из: В. Spolsky and F. М. Hult (ур.) The Handbook of Educational Linguistics (пп. 297 - 312). Оксфорд, УК: Blackwell Publishing Ltd.

\section{Извори:}

Званична интернет страница Владе Републике Србије. Доступно преко: https://www.srbija.gov.rs/tekst/37/nacionalne-manjine.php [20.06.2018.].

Званична интернет страница Министарства културе и наслеђа Новог Зеланда (New Zealand History). Доступно преко: https://nzhistory.govt.nz/culture/ maori-language-week/history-of-the-maori-language [29.05.2018.].

Званична интернет страница организације UNESCO (United Nations Educational, Scientific and Cultural Organization). Доступно преко: http://www.unesco.org/new/en/culture/themes/endangered-languages/faqon-endangered-languages/ [24.12.2017.]

Образовне политике за унапређивање права националних мањина (2017). Извешйај Министиарстива иросветее, науке и иеехнолошкої развоја Реиублике Србије. Доступно преко: http://www.mpn.gov.rs/wp-content/up 
РЕЛЕВАНТНОСТ КОНЦЕПТА РЕВИТАЛИЗАЦИЈЕ ЈЕЗИКА ...

loads/2017/06/\%D0\%9Ebrazovanj\%D0\%B5-nacionalnih-manjina-1.pdf [10.05.2018.].

Правилник о допуни Правилника о наставном плану и програму за први и други разред основног образовања и васпитања ("Сл. гласник РС - Просветни гласник", бр. 6/2017). Доступно преко: https://www. paragraf.rs/izmene_i_dopune/060717-pravilnik_o_dopuni_pravilnika_o_ nastavnom_planu_i_programu_za_prvi_i_drugi_razred_osnovnog_ obrazovanja_i_vaspitanja.html [10.05.2018.].

\section{Irena M. Kužnik}

Borko N. Kovačević

THE RELEVANCE OF LANGUAGE REVITALIZATION CONCEPT FROM MODERN LANGUAGE POLICIES' PERSPECTIVE

\section{Summary}

Language revitalization is developed as a product of interaction by majority and minority languages within a social, political and economic environment. This implies studying the position of a language in a community through the prism of the community itself, through each of its individual members, as well as through language policies which, to an extent, can impose certain perceptions about one's language, identity and culture.

On the other hand, the creation and scope of language policies are influenced by cultural models and ideologies established within the community itself. Moreover, this suggests that language standardization is the precondition for successful revitalization, as well as for the development of positive attitude towards the ethnical language within both communities - the minority one and the majority one.

In addition to illustrating many successful examples of language revitalization, the paper specifically deals with the Slovene language and its current status in the education system of the Republic of Serbia.

Key words: language revitalization, language policy, speech community, minority language, Slovenian 